\title{
Andrzej Zawadzki Rzeźbiarz i filozof. Constantin Brâncuşi w interpretacjach Constantina Noiki
}

\begin{abstract}
Zawadzki Andrzej, Rzeźbiarz i filozof. Constantin Brâncuşi w interpretacjach Constantina Noiki [Sculptor and philosopher. Constantin Brâncuşi in Constantin Noica's interpretations]. "Przestrzenie Teorii" 29. Poznań 2018, Adam Mickiewicz University Press, pp. 315-328. ISSN 1644-6763. DOI 10.14746/pt.2018.29.12.
\end{abstract}

The article Sculptor and philosopher deals with the Romanian thinker Constantin Noica's interpretations of Constantin Brâncuşi's work. These interpretations are presented with regard to Noica's philosophical concepts, in particular his reflections on Romanian culture and the sense of being manifested within it. Of fundamental importance in his interpretations is the category of becoming within being - the most important idea developed by Noica and which he applied in many fields of philosophy.

KEYWORDS: Constantin Noica, Constantin Brâncuşi, ontology, philosophy of art, sculpture, Romanian culture

Dla Domisi

Z rzeźbami Brâncuşiego spotykałem się trzykrotnie. Spotkanie pierwsze i, muszę przyznać, najmniej udane miało miejsce w Paryżu, czyli miejscu, w którym artysta się osiedlił: nie dotarłem do atelier rzeźbiarza przy muzeum Pompidou, ostatecznie widziałem tylko Pocałunek na cmentarzu Montparnasse. Rzeźby musieliśmy długo szukać, ostatecznie znaleźliśmy, ale wtedy nie zrobiła na mnie dużego wrażenia, jakby wciśnięta w kąt cmentarza i mniejsza, skromniejsza, niż się spodziewałem. Drugie spotkanie odbyło się w Wenecji, gdzie w muzeum Peggy Guggenheim można zobaczyć Maiastrę i Ptaka w przestrzeni. Wreszcie spotkanie trzecie, tymczasem ostatnie, najważniejsze i najbardziej świadome, choć odbyte w nieco turystycznym klimacie. Od Stasiukowego Babadagu i Konstancy jechaliśmy tak zwana autostradą słońca do Bukaresztu. Jeden nierozważny skręt w miejscu, które od tego czasu zawsze, jadąc autobusem z lotniska Otopeni, oglądam z góry, rozpamiętując swoją wstydliwa porażkę jako kierowcy, spowodował, że zamiast jechać prosto na Piteşti, znaleźliśmy się nagle na trójpasmówce do stolicy. Pobłądziwszy trochę na mało mi znanych peryferiach północnego 
Bukaresztu, wyjechaliśmy w końcu na jakąś nieoświetloną i wyboistą drogę wiodącą mniej więcej w pożądanym przez nas kierunku. Ujechaliśmy trochę, mapa wskazała, że najbliższą większą miejscowościa, w której można by liczyć na w miarę godziwy nocleg - zbliżała się noc, zmęczenie całodzienną jazdą dawało się coraz bardziej we znaki - jest niewielkie miasto Râmnicu Vâlcea, którym widziałem tyle tylko, że urodził się w nim Gabriel Lîiceanu, znany filozof i uczeń Constantina Noiki. Znaleźliśmy w przewodniku kilka polecanych hoteli, zachodząc w głowę, jak je po nocy znajdziemy, skręciliśmy do miasta. Szczęście nam dopisało: dość szybko zobaczyliśmy jakiśs hotel, zatrzymaliśmy się, wyglądał przyzwoicie, były wolne miejsca, zostaliśmy, choć nie figurował na przewodnikowej liście. Z tego hotelu zapamiętałem najlepiej trochę niesamowitą windę o dziwnym oświetleniu i duże korytarze, kojarzące się z filmami grozy, oraz mecz między Steauą Bukareszt a - chyba - CSKA Sofia w eliminacjach Ligi Mistrzów, którego końcówkę oglądałem w telewizorze (jeśli dobrze pamiętam, my, czyli Steaua, wygraliśmy dwa do zera). Râmnicu Vâlcea, położone ładnie wśród łagodnych wzniesień, okazało się rano miastem bardzo sympatycznym, choć nie dane nam było poznać go bliżej, bo czas naglił, a atrakcje czekały. Dalsza droga wiodła, obowiazkowo, do pięknego, zabytkowego klasztoru Horezu, znakomitego przykładu architektury z czasów hospodara Constantina Brâncoveanu, od którego wzią swą nazwę cały styl w osiemnastowiecznej sztuce Wołoszczyzny (stilul brâncovenesc), a następnie do Târgu Jiu, gdzie można oglądać Niekończaca się kolumnę, Bramę pocałunku i Stót milczenia. Znałem już wtedy szkice Noiki o rzeźbach Brâncuşiego i byłem ciekaw zwłaszcza Kolumny, do której filozof odnosił się najczęściej.

W szkicu Trei mari gânditori români [Trzej wielcy rumuńscy myśliciele] Noica pisze: „Nasza kultura miała w przeszłości trzech wielkich myślicieli, którzy mieli postawić przed sobą problem bytu: język, poetę i rzeźbiarza”1. Językowi rumuńskiemu i jego głębokim filozoficznym sensom poświęcił obszerne rozważania zwłaszcza w dwóch książkach: Rostirea filozofică românească oraz Creație şi frumos în gândirea filozofică românească, zebranych następnie w wydanym pośmiertnie tomie Cuvânt împreuna despre rostirea filozofică românească $\breve{2}^{2}$ Łącząc dociekliwość filologa z konceptualną praca filozoficzna, Noica w bardzo interesujący sposób ukazał myślowy i duchowy świat, zapisany w jego ojczystym języku, specyficznie rumuńskie odczucie bytu - jak głosi tytuł jednej z jego książek ${ }^{3}$. Odzwierciedla się ono zarówno w słowach właściwych dla dyskursu filozoficznego, takich jak byt, natura,

\footnotetext{
${ }^{1}$ Zob. C. Noica, Introducere la miracolul eminescian, Bucureşti 2010, s. 375.

${ }^{2} \mathrm{~W}$ dalszym ciąu niniejszego tekstu odwołuję się do drugiego wydania tej książki, które ukazało się w Bukareszcie, w wydawnictwie Humanitas w roku 2000.

${ }^{3}$ Chodzi o książkę Sentimentul românesc al ființei z 1978 roku.
} 
stawanie się, czy trudno przetłumaczalny przysłówek „întru” - będzie o nim jeszcze mowa w dalszej części tego tekstu, jak i w wyrażeniach potocznych. To prawdziwie hermeneutyczne przedsięwzięcie jest twórcza kontynuacją bliskiej Heideggerowi i Gadamerowi idei, że autentyczne doświadczenie świata odbywa się zawsze w języku.

Drugim wspomnianym przez Noikę myślicielem jest Mihai Eminescu, piszący w drugiej połowie XIX wieku romantyk, uważany za najwybitniejszego rumuńskiego poetę, twórca obdarzony dużą wyobraźnią filozoficzna, o czym świadcza jego bogate, acz fragmentaryczne zapiski, który zresztą podczas swych studiów w Wiedniu i Berlinie poznał dobrze filozofię niemiecka, zwłaszcza Kanta, a nawet przełożył na rumuński fragmenty Krytyki czystego rozumu. W książce Eminescu sau gânduri despre omul deplin al culturii româneşti (1975) Noica skupia się właśnie na filozoficznych intuicjach zawartych w dziełach poety, a przede wszystkim traktuje go jako - by znów odwołać się do tytułowej formuły książki - człowieka spełnionego rumuńskiej kultury, twórcę, który stał się tej kultury świadomościa, niejako wcielił w siebie jej uniwersalne sensy, czy też - by użyć drogich Noice terminów Heglowskich - przekształcił ją z substancji w podmiot ${ }^{4}$.

W zestawieniu z książkami na temat języka rumuńskiego oraz Eminescu, korpus tekstów Noiki poświęconych twórczości Constantina Brâncuşiego - on to bowiem jest trzecim z wymienionych przez filozofa myślicieli - przedstawia się stosunkowo skromnie. Oprócz przełożonych tu tekstów znane mi sa jeszcze trzy szkice, które Noica poświęcił twórcy Niekończqcej się kolumny i Rozważności Ziemi - są to eseje zamieszczone we wspomnianych już Rostirea filozofică românească oraz Creație şi frumos în rostirea românească. Sądzę jednak, że Brâncuşi, urodzony w roku 1876, doczekał się w swym młodszym o ponad trzydzieści lat rodaku interpretatora wnikliwego i konsekwentnego, a teksty Noiki, poświęcone rumuńskiemu artyście, choć niewielkie objętościowo, zasługują w pełni na włączenie do kanonu „filozofii rzeźby”, obok prac między innymi Patera, Heideggera czy Serresa ${ }^{5}$.

Czas i kontekst powstania szkiców Noiki o rzeźbach Brâncuşiego pozwalają spojrzeć na te teksty jako na pewną spójna myślową całość, osadzoną mocno w koncepcjach filozofa i rytmie ich ewolucji. Książki Rostirea filozo-

${ }^{4}$ Oprócz wspomnianej książki Noica poświęcił poecie liczne artykuły, zawierające zarówno interpretacje jego twórczości, jak i na przykład różne noty i odezwy, w których domagał się uznania dla mniej znanej, niż czysto poetycka części dorobku rumuńskiego romantyka. Całość tekstów filozofa poświęconych Eminescu zawiera wspomniany w przypisie 1 tom C. Noica, Introducere la miracolul eminescian.

${ }^{5}$ Odwołuję się tu do nieopublikowanej jeszcze (podczas pisania przeze mnie tego szkicu) książki Katarzyny Trzeciak Posagi i utopie: rzeźba jako metafora nowoczesnej formy artystycznej, podmiotowości i politycznej wspólnoty. 
fică românească oraz Creație şi frumos în gândirea filozofică românească, pochodza, odpowiednio, z roku 1970 oraz 1973, tekst o Rozważności Ziemi ukazał się w roku 1975, a ten o Niekończqcej się kolumnie jest fragmentem książki Sentimentul românesc al ființei, opublikowanej w roku 1978. Te daty pokazuja, że twórczość Brâncuşiego towarzyszyła Noice przez całą dekadę; co więcej, lata siedemdziesiąte to w twórczości tego myśliciela okres, w którym pisał najwięcej o kulturze rumuńskiej widzianej z perspektywy filozoficznej, o wspomnianym wyżej „rumuńskim odczuciu” bytu, czyli swoistej etnicznej ontologii, zapisanej i wyrażającej się zarówno w, o czym była już mowa, głębokich pokładach języka, jak i w twórczości kulturowej, zarówno popularnej, folklorystycznej - jak na przykład interpretowana przez niego w Sentimentul românesc al ființei baśń Tinerețe fără bătrânețe [Młodość bez starości], jak i wysokiej, zwłaszcza u Eminescu i właśnie Brâncuşiego.

Medytacje nad własną kulturą nie więżą myśli Noiki w jakimś wąskim etnocentryzmie; są one, by użyć jego własnego terminu, „zamknięciem, które otwiera". Fenomen rumuńskości, rumuńska wizja bytu, choć specyficzne i niepowtarzalne, nie są ani idiosynkratyczne, ani ograniczające, lecz przeciwnie: nie wbrew, lecz właśnie dzięki swej odrębności i szczególności stanowią ważną ścieżkę ku kulturowym i duchowym uniwersaliom, których organiczną część stanowią. Takie podejście do relacji między partykularnością a powszechnością zaobserwować można, przyglądając się temu, jak wyglądała myślowa droga Noiki: wiele pojęć i kategorii, wypracowanych $\mathrm{w}$ interpretacjach najwybitniejszych i najbardziej charakterystycznych dzieł rumuńskiej kultury zostanie wykorzystanych przez filozofa w bardziej teoretycznych pracach z ósmej dekady XX wieku, których zwieńczeniem jest obszerny traktat Devenirea întru ființa z 1981 roku.

Znaczenie twórczość Brâncuşiego w myśleniu Noiki polega między innymi na tym, że tworzy ona swego rodzaju pomost między okresem, w którym ten ostatni najintensywniej rozmyślał o fenomenie rumuńskości i jego specyfice, a tym, w którym powstała jego dojrzała koncepcja ontologiczna. Z jednej strony Noica bardzo wyraźne podkreśla, że choć dzieło Brâncuşiego ma charakter uniwersalny, to jego korzenie tkwią w tradycji rumuńskiej; z drugiej strony, we wszystkich interpretacjach dzieł rzeźbiarza Noica powraca do problemu skończoności i nieskończoności, a w chronologicznie ostatnim szkicu, tym z Sentimentul românesc al ființei, stosuje wprost pojęcie, czy też kategorię, która odegra - oczywiście w postaci o wiele bardziej rozbudowanej i podbudowanej teoretycznie - kluczową rolę w jego ontologii: stawanie się ku bytowi. Jego szkice o Brâncuşim można więc także traktować jako dokument świadczący o dojrzewaniu tego podstawowego Noikowego terminu, który, także przez to, że jest praktycznie nieprzekładalny, nadaje myśleniu rumuńskiego filozofa niepowtarzalny charakter. 
Najpierw więc o dwóch szkicach z Rostirea filozofică românească, jak się zdaje, najwcześniejszych zapiskach Noiki na temat Brâncuşiego. Ich miejsce w kompozycji książki jest istotne - filozof umieścił oba w części zatytułowanej Ciclul devenirii, cykl stawania się, która następuje po części poświęconej pojęciom i kategoriom składającym się na cykl bytu, Ciclul ființei. Bezpośrednio poprzedza je szkic o nieskończoności u Eminescu, co pokazuje, że i u poety, i u rzeźbiarza filozof szukał odpowiedzi na podobne pytania, a twórczość obu umieszczał nie w perspektywie bytu statycznego, lecz dynamicznego dziania się, procesualności.

W szkicu Îndoita infinire la Brâncuşi Noica traktuje trzy rzeźby Brâncuşiego z Târgu Jiu - Niekończqca się kolumnę, Bramę pocałunku i Stót milczenia - nie jako odrębne dzieła, lecz jako spójną całość, obdarzoną nadrzędnym sensem. Co więcej, do całości tej włącza pewne elementy miejskiego pejzażu, traktując rzeźby jako sztukę nierozerwalnie, organicznie wrośniętą w miejsce, w którym zostały ustawione; dziś być może użylibyśmy tu terminu sztuka in situ, site-specific. Elementami tymi są kościół Świętych Apostołów z Târgu Jiu oraz „nowy kamienny stół, tym razem bez krzeseł, ustawiony być może przez Brâncuşiego lub za jego sugestia, za Kolumna [...]”6. Noica, który miał wyraźne upodobanie do liczby sześć - podwojonej triady dialektycznej - i za jej pomocą porządkował różne obszary rzeczywistości i doświadczenia, wyróżniając między innymi sześć duchowych chorób, sześć funkcji pytania, sześć sytuacji ontologicznych czy sześć typów myślenia, tym razem pozostał przy układzie złożonym z pięciu elementów. Ma on w istocie charakter narracyjny, jest, jak mówi Noica, opowieścia, legenda, eposem, można w nim zobaczyć, na przykład, ukazany przestrzennie legendarny przekaz o założycielach rumuńskiej państwowości, ustanawiających podstawowe dla siebie loci: miejsce rady, graniczną bramę, miejsce kultu, czy też, szerzej, życia społecznego, wreszcie wzniosły wyraz swych dążeń i aspiracji. Ów pięcioskładnikowy układ wyraża też jednak coś głębszego i bardziej uniwersalnego, a mianowicie samą strukturę każdej legendy. Filozof przywołuje w tym miejscu kontekst dość odległy i zaskakujący - Pięcioksiąg Starego Testamentu. Oto każda opowieść ma swą genezis, milczące stworzenie, początek biorący się z samej myśli; dalej moment wyjścia, exodusu, czyli rozwinięcia, po którym następuje organizacja, uporządkowanie, ustanowienie, mające swój odpowiednik w Księgach Lewitów i Liczb; następnie Księga Powtórzonego Prawa, interpretowana jako moment ewokacji i profetyzmu, a w kategoriach świeckich - powrotu myśli do samej siebie, przemyślenia, refleksji następującej po czynie, co jest największym osiagnięciem człowieka; w końcu znów moment milczenia - nieznany grób Mojżesza. Pięć ksiag

${ }^{6}$ Zob. C. Noica, Cuvânt împreună despre rostirea românească..., s. 81-82. 
Pentateuchu, pięć składników wszelkiej opowieści, pięć elementów stworzonego przez Brâncuşiego rzeźbiarskiego układu.

W układzie tym najistotniejszy, bo najbardziej „refleksyjny”, niosący największy ładunek konceptualny jest element czwarty - Niekończqca się kolumna. W istocie sa dwie kolumny - stąd pewnie w tytule szkicu słowo indoita, czyli podwójna, podwojona - ta horyzontalna i ta wertykalna, wytyczona linią złożoną z pięciu wymienionych elementów. Obie są zamknięte i otwarte, skończone i nieskończone jednocześnie - drugi, mniejszy stół kończy i jednocześnie zaczyna od nowa cały układ, czy, jak powiada Noica, cykl, podobnie jak zamykają się i otwieraja romboidalne elementy samej Kolumny; ostatni z nich ją zwieńcza, ale też szerszym bokiem zwraca ku niebu. Zamknięcie i otwarcie, skończoność i nieskończoność:

Cała Kolumna to nieskończoność w skończoności, czy też skończoność otwarta; zaś te pięć momentów to też nieskończoność w skończonym, lub struktura otwarta. W układzie wykreowanym przez Brâncuşiego jest nieskończoność w linii wertykalnej, tej tworzonej przez Kolumnę, i nieskończoność w linii horyzontalnej - rozwinięcie się samego układu. W strukturę każdej epickiej legendy powinno być wpisane niekończenie się historii ${ }^{7}$.

Jako „niekończenie się” próbuję oddać nienotowany w słowniku rumuńsko-polskim termin infinire: we wspomnianym szkicu, zatytułowanym Infinit şi infinire la Eminescu [To, co nieskończone i niekończenie się u Eminescu] Noica wyjaśnia zasadność rozróżnienia między nieskończonym a niekończeniem się: „Widzieliśmy, że niekończenie się [infinire] nie pokrywa się w pełni z idea tego, co nieskończone [infinit]. Powinno być dopełnione nowym terminem, nie-kończenie się [în-finire], na oznaczenie nieskończonego implantowanego w skończonym"8. Nieskończone jest masywne, wyraża zatratę $\mathrm{w}$ tym, co nieskończenie wielkie lub nieskończenie małe, niekończenie się to nieskończone, ale-łagodne, możliwe do zniesienia, które, co może szczególnie ważne i intrygujące, zawiera w sobie niekończące się odsyłanie ku czemuś innemu. Może więc skończoność i nieskończoność to także inaczej nazwane tożsamość i inność, nie przeciwstawne, lecz ściśle ze sobą złączone? Według Noiki wszystko znajduje się w stanie niekończenia się, które nie jest ani skończonym, ani nieskończonym ${ }^{9}$. Skończone nie jest zatem zamknięte ani ograniczone - i ograniczające - bo zawsze ma w sobie moment otwierania się ku nieskończonemu; z kolei nieskończone nie oznacza bez-miaru, czegoś przerażającego swą bezgranicznościa, nieogarnialnościa, w której wszystko się gubi i ulega zatracie, lecz dane jest zawsze w czymś

\footnotetext{
7 Tamże, s. 85.

8 Tamże, s. 77.

${ }^{9}$ Tamże, s. 78-79.
} 
skończonym, nie tracąc przy tym swej natury: to właśnie zdają się mówić i Eminescu, i Brâncuşi w Niekończqcej się kolumnie.

Ten sam wątek - nieskończoności oswojonej przez to, co skończone rozwija Noica w kolejnym szkicu o Brâncuşim, Supliment la infinire [Dodatek do niekończenia się]. Powtarza, że niekończenie się to „łagodna nieskończoność", dodaje, że jest ona udostępnionym niedostępnym, strawnym, sprowadzonym do ludzkiej miary nieskończonym, akcentuje również w tym stosunku Brâncuşiego do nieskończoności znamienne dla rumuńskiego ducha „odrzucenie gigantyzmu” ${ }^{10}$, niechęć do monumentalizmu i wielkich wymiarów, które już wcześniej zauważał w architekturze „naszych cerkiewek” by odwołać się do tytułu jednego ze szkiców z ksiazżi Pagini despre sufletul românesc z 1944 roku $^{11}$ - czyli słynnych malowanych cerkwi z Bukowiny.

Z kolei w szkicu Brâncuşi a sculptat infinitive lungi [Brâncuşi wyrzeźbił długie bezokoliczniki] Noica szuka klucza do twórczości rzeźbiarza w gramatycznej formie bezokolicznika. Gra słów, którą wykorzystuje filozof, jest niemożliwa do oddania po polsku: po rumuńsku nieskończony to infinit, a bezokolicznik to infinitiv, podobnie rzecz ma się w innych językach romańskich. Jeśli jeszcze doda się do tego fakt, że rumuńskie rzeczowniki odczasownikowe, czyli gerundia - które filozof określa jako „długie bezokoliczniki” - przypominają końcówkami łacińskie infinitiva, myśl Noiki staje się jasna. Brâncusi niejako rzeźbi gramatykę, ukazuje środkami rzeźbiarskimi to, co mówi język rumuński, ale nie interesuja go substantiva, rzeczowniki, które, jak twierdzi rumuński filozof, dominują u Breughla, ani nie przymiotniki, które malował Rubens, lecz te formy, które wyrażają dynamikę i niekończenie się. Innymi słowy, przedstawia nie to, co dojrzałe, ale dojrzewanie, nie to wzniosłe, ale wznoszenie się, nie lot, ale latanie, nie to, co dopełnione, ale ciagłe dopełnianie się jako „nieustającą pieszczotę form, podobną kamieniowi, obmywanemu przez wodę"12.

Zamieszczone tu w przekładzie dwa teksty Noiki wydają się najbardziej dopracowane ze wszystkich jego szkiców o rumuńskim rzeźbiarzu, tak myślowo, jak i pod względem ich literackiej kompozycji, myślę, że są bardzo dobrym przykładem wyrafinowanego filozoficznego eseju; być może należałoby je też uznać za ostatnie, w porządku myślowym, słowo Noiki o dziele Brâncuşiego. Oba eseje są też ze sobą ściśle powiązane, tworzą wręcz myślową całość, jeśli nie wręcz jeden tekst: esej o Kolumnie kończy się nawiązaniem do tego o Rozważności Ziemi i zapowiada jego problematykę.

Nie chcę zbędnymi komentarzami psuć potencjalnemu czytelnikowi satysfakcji z lektury tych tekstów, ograniczę się zatem tylko do wypunkto-

${ }^{10}$ Tamże, s. 88.

${ }_{11}$ Zob. tenże, Pagini despre sufletul românesc, wyd. II, Bucureşti 2000, s. 43-45.

${ }^{12}$ Zob. tenże, Cuvânt împreună despre rostirea românească..., s. 299-300. 
wania kilku spraw podstawowych. Omówione wcześniej szkice myśliciela poświęcone twórczości Brâncuşiego były zdecydowanie „logocentryczne”: filozof dosłownie i w przenośni czytał rzeźby, traktował je przez pryzmat opowieści, czy nawet kategorii gramatycznych, jak i, oczywiście, zawartego w nich sensu i potencjału pojęciowego. Podpisałby się zapewne pod stwierdzeniem Heideggera, że sztuka jest w istocie poetyzacja, ale pojęta oczywiście szeroko, jako fundowanie prawdy ${ }^{13}$. Brâncuşi dla Noiki był tym, kim był dla Heideggera Hölderlin; w „sojuszu poety i myśliciela” ${ }^{14}$ oraz myśliciela i rzeźbiarza chodzi w istocie o to samo - o to, by sztuka, jako poezja w znaczeniu „ujęcia językowego"15 czy też legendy, eposu, powieści lub nawet ufilozoficznionej formy gramatycznej, „wiodła byt w całości ku jego prawdzie"16. W obu przełożonych tu szkicach Noica jakby wycisza logos rzeźb Brâncuşiego, zwraca natomiast większą uwagę na materialność interpretowanych dzieł, na stricte rzeźbiarskie szczegóły (zwłaszcza w przypadku Rozważności Ziemi); w obu wprowadza dość osobliwą figurę pozaziemskiego obcego, który chce coś zrozumieć z ludzkiego bytowania na świecie, a wreszcie, co najistotniejsze, w obu w pełni już wykorzystuje pojęcie stawania się ku bytowi, któremu wypada teraz poświęcić nieco więcej uwagi, choć jego wyczerpujacce przedstawienie wymagałoby osobnej, i to wcale obszernej rozprawy.

Problematyka stawania się ku bytowi pojawia się u Noiki w latach pięćdziesiątych, bo z tego czasu pochodzą teksty, które złożyły się na książkę Despărțirea de Goethe [Pożegnanie z Goethem, dosłownie: Odejście od Goethego], wydana ostatecznie w roku 1976, i powraca w jego myśli właściwie nieprzerwanie, by swój najdojrzalszy, a jednocześnie najbardziej techniczny kształt przybrać w filozoficznej summie Noiki, czyli traktacie Devenirea intru ființa. Streszczam główne wątki rozważań Noiki. Byt, którego pojęcie panowało nad całą myślą starożytna, i stawanie się, które zawładnęło wyobraźnią nowożytna, były przeważnie traktowane jako przeciwieństwa. Czy można jednak pomyśleć relację bytu i stawania się niesprzecznie, tak, by nie dzielić arbitralnie rzeczywistości i nie kaleczyć naszego jej doświadczania? Wszak byt, z którego wyłączony jest moment stawania się, czyli zmiany, jest trwały, lecz trwałością zastygłej bryły lodu, spełniony, ale spełnieniem śmierci. Z kolei stawanie się, pozbawione jakiegokolwiek zako-

${ }^{13}$ Zob. M. Heidegger, Źródto dzieła sztuki, [w:] tegoż, Drogi lasu, przeł. J. Gerasimiuk i inni, Warszawa 1997, s. 53.

${ }_{14}$ Zob. C. Wodziński, Kairos. Konferencja w Todtnaubergu. Celan-Heidegger, Gdańsk 2010, s. 86.

${ }^{15}$ Tamże, s. 75.

${ }^{16}$ Zob. O. Pöggeler, Droga myślowa Martina Heideggera, przekł. B. Baran, Warszawa 2002, s. 249. 
rzenienia w bycie to sama płynność, upływ, zatracanie się. Noica wyróżnia kilka form stawania się: najniższą jest ślepe, proste stawanie się rzeczy, wyższa stawanie się, któremu towarzyszy świadomość siebie, czyli takie, w którym nie same rzeczy się liczą, a to, jak są odczuwane przez jednostkę, najwyższą zaś - stawanie się złączone z świadomością obiektywna, polegające na włączeniu stawania się na poziomie jednostki w jakiś szerszy ruch stawania się. Wszystko to jednak są przejawy zjawiska, które filozof określa jako devenirea întru devenire, stawanie się ku stawaniu, czyli stawanie się, które służy tylko dalszemu stawaniu się, pomnaża je i w nim się całkowicie wyczerpuje, a którego przykładami są między innymi organiczne trwanie, prokreacja, akumulacja dóbr. Stawanie się ku stawaniu to czysta repetycja, addytywność, reprodukcja, zmiana dążąca donikąd i znajdująca wyraz w linii ciagłej. Tylko z pozoru otwiera ono horyzont nieskończoności, a $\mathrm{w}$ istocie jest tylko powtarzaniem w nieskończoność tego, co skończone, jego nieskończoność jest, jak pisze Noica, który w tamtym czasie znajdował się pod znacznym wpływem Hegla i jego terminologii, złą nieskończonością i ostatecznie prowadzi do niebytu.

Istnieje jednak inna modalność stawania się, taka, która stanowi istotny wymiar bytu jako takiego, ale go nie niszczy ani nie osłabia, taka, która bytowi służy, ale nie zostaje przez jego niezmienność i solenność rozbrojona i unicestwiona. Jej rytm wyznacza nie prosta, ale krag, nie powracanie wciąż tego samego, lecz integrowanie nowych elementów i włączanie ich w coraz szersze całości. Noica nazywa tę ontologiczną modalność właśnie stawaniem się ku bytowi - devenirea întru ființa - i, podobnie jak w przypadku stawania się ku stawaniu, dostrzega różne jej odmiany: od spełnienia na planie jednostkowym, które narratywiści określiliby zapewne jako zbudowanie spójnej i obdarzonej całościowym sensem opowieści dobrego życia, które jest czymś więcej niż zwykła, banalna egzystencja; przez spełnienie na poziomie obiektywnym, czyli stworzenie wspólnoty, która nie jest tylko zwykłą organizacja polityczna, zrzeszająca podmioty połączone jedynie zewnętrznymi relacjami, ale podąża za jakąś szerszą idea, czyli zdolna jest do stworzenia kultury; po poziom absolutny, który najpełniej ujawnia się w religii, w postaci jednostki wcielającej w siebie człowieczeństwo jako takie. Ostatni poziom, który Noica utożsamia z głęboko pojętą dialektyka, wykracza już nawet poza sferę tego, co ludzkie - choćby ujęte w wymiarze absolutnym - i polega na, jak mówi filozof, pogodzeniu logosu człowieka $\mathrm{z}$ logosem rzeczy, czyli na pełnym zrealizowaniu się rozumności w świecie ${ }^{17}$.

Stawanie się ku bytowi jako ontologiczna modalność obiecuje, jak sądzi Noica, bardzo wiele, bo nie mniej, tylko pogodzenie tego, co czasowe, z tym,

${ }^{17}$ Zob. C. Noica, Despărțirea de Goethe, Bucureşti 2000, s. 257--293. 
co pozaczasowe, skończoności i nieskończoności, realnego i idealnego, bezpośredniości i absolutu ${ }^{18}$. Można jednak powiedzieć, że cały ten potężny i ambitny program zawisł na włosku, czyli na przysłówku întru, o którym, gdyby przysłówkiem nie był, można by powiedzieć, że „jest systemem filozoficznym"19. Otóż wspomniany przysłówek, pochodzący od łacińskiego czasownika intrare, znaczącego wchodzić, wkraczać, znaczy zarówno „w”, jak i „ku”, obrazuje więc sytuację statyczną (bycie w czymś, w jakimś stanie lub sytuacji), jak i dynamiczną (stawanie się, wkraczanie w jakiś stan bądź wykraczanie ku niemu). Jego unikalność, jak też filozoficzny potencjał polegają na tym, że nie wskazuje on na wyłącznie przestrzenne, lecz także czasowe relacje między rzeczami. Noica podkreśla różnicę pomiędzy sytuacja „bycia w” (a fi în) oraz bycia w/ku (a fi întru). Ta pierwsza wyraża sytuację zamknięcia, ograniczenia, ta druga wprawdzie też odnosi do pewnego osadzenia w jakimś stanie, takiego jednak, które ma potencjał rozwoju, wykraczania poza siebie, otwarcia na nowe horyzonty bycia.

Przyjrzyjmy się teraz temu, jako owo stawanie się ku bytowi przejawia się w Niekończqcej się kolumnie i Rozważności Ziemi. Noica pisze wprost, że ta pierwsza została obmyślona przez rzeźbiarza jako stawanie się ku bytowi, i tak po prostu - Devenirea întru ființa - zatytułowany jest fragment książki Sentimentul românesc al ființei, w którym filozof interpretuje to dzieło Brâncuşiego, widząc w nim - jeśli można się tak wyrazić - raczej byt niż wartość, czyli sytuując je wyraźnie w porządku ontologicznym, a nie estetycznym. Takiemu ustawieniu akcentu służy wprowadzona na początku eseju figura obcego: nawet ktoś niemający najmniejszego pojęcia o naszym, ludzkim wyobrażeniu piękna pojmie coś - „coś” - z rzeźb Brâncuşiego dlatego właśnie, że przejawia się w nich jakaś idea bytowania w ogóle. Stawanie się ku bytowi ogarnia sobą inne przeciwieństwa, także te, o których Noica wspominał w swych wcześniejszych szkicach o rumuńskim rzeźbiarzu, takie jak skończoność i nieskończoność, otwarcie i zamknięcie. Teraz dochodzą do nich inne: statyczny, „nieruchomy” Parmenides i dynamiczny, „płynący” Heraklit oraz ściśle z nimi powiązani Apollo i Dionizos, patronujący, odpowiednio, formie zamkniętej oraz otwartej, jak też wnętrze i zewnętrze, wspomniane a propos Koguta oraz obecność i nieobecność, która ewokuje Stót milczenia. To, co wewnętrzne, i to, co obecne to oczywiście inne imiona bytu, tradycyjnie pojmowanego w myśli zachodniej jako trwała, niezmienna natura rzeczy; to, co zewnętrze i to, co nieobecne pseudonimują stawanie się, jako brak bytu, to, co leży poza jego prawdziwą istotą i jako takie podlega zepsuciu. Zadaniem skromnego przysłówka întru - jak i jego wielka ontolo-

\footnotetext{
18 Tamże, s. 263.

${ }^{19}$ Zob. tenże, Cuvânt împreună despre rostirea românească..., s. 40.
} 
giczna zasługa - jest umożliwienie innego niż opozycyjne pomyślenia tych kategorii i ukazania stawania się ku bytowi. Tym razem jednak Kolumna nie opowiada o tej relacji, ale daje jej wyraz samą swą istotą: „Brâncusi natomiast nie mówi nam o tym, lecz otwiera na to oczy, w rzeźbie”. Ogólność materii przyjmuje jednostkowa postać w konkretnym dziele z niej wykutym, a jej ciężar wzbija się w lot, który jednak nie oznacza „ulotnienia się”, czyli unicestwienia, zniesienia, wchłonięcia materialności przez duchowość. Przeciwnie - lekkość jest już $w$ ciężarze i dlatego może $k u$ niemu wykraczać, oraz vice versa - wzajemne wykraczanie $k u$ sobie tych jakości czyni możliwym to, że jedna jest $w$ drugiej.

Drugi z przestawionych tu tekstów, poświęcony Rozważności Ziemi, ma interesująca historię. Ukazał się po raz pierwszy w roku 1975 w czasopiśmie „Steaua”. Niedawno wydał go ponownie Gabriel Lîiceanu w tygodniku „Revista 22 " i to z internetowego wydania tego pisma wziąłem tekst oryginału. Okazją dla tej reedycji była toczaca się kilka lat temu w Rumunii dyskusja wokół planowanego wykupienia rzeźby przez rząd rumuński z rąk prywatnych właścicieli. Uczeń Noiki wydał esej swojego mistrza wraz z jego „interpretacja”" autorstwa współpracownika rumuńskiej bezpieki, niejakiego Octaviana Chetana alias „Cristiana” (Lîiceanu zresztą poświęcił mu wydaną w 2013 roku książkę Dragul meu turnător), który napisał datowaną na 19 lutego 1976 roku notę informacyjną o tekście Noiki, przeznaczoną dla użytku oficera Securitate, majora Ioana Pătrulescu. Ten ostatni był, co interesujące, „oficerem prowadzącym” zarówno Noiki, jak i samego Lîiceanu. Przez wydanie obu tekstów razem autor Dziennika z Pălținişu chciał, jak o tym pisze w swym komentarzu, z którego zaczerpnąłem wyżej podane fakty, pokazać dystans dzielący wyrafinowany tekst filozofa od bełkotu informatora komunistycznej bezpieki, tak dobrze zresztą znanego również w Polsce i całej środkowej Europie. Towarzysz Chetan wyczytał w tekście Noiki między innymi pogardę dla ludów afrykańskich i rumuńskich chłopów, pozbawionych rzekomo urody i inteligencji.

Również w szkicu Noiki o Rozważności Ziemi cała interpretacja rzeźby jest osnuta wokół pojęcia stawania się ku bytowi, jest ono jednak nieco inaczej, niż w szkicu o Kolumnie wyprofilowane. Na pierwszy rzut oka wydaje się, że mamy do czynienia z ujęciem ewolucyjnym, służącym pokazaniu wznoszenia się człowieka od prymitywności do cywilizacji i kultury, od natury do człowieczeństwa i refleksyjności. Gdyby tak jednak było, rzeźba byłaby jakby pęknięta na dwie części, a tak nie jest - przeciwnie, Noica podkreśla, że stawanie się ku bytowi, przejawiające się w rzeźbie, bynajmniej nie niszczy jej tożsamości, co więcej, wyraża niekończące się wychylanie ku sobie pozornie sprzecznych elementów, przybierające postać kolistą czy spiralna, a nie prosty i jednokierunkowy postęp, co do którego zresztą Noica 
był nieufny i widział w nim raczej przejaw stawania się ku stawaniu. Opozycyjne elementy, które filozof odnajduje w rzeźbie, znajdują się w stanie równowagi, wskazuja na jakąś trudną do nazwania sferę, która zawiera $w$ sobie zalążkowo stawanie się, sam ruch $k u$ czemuś, jakiemuś bytowi, czy może raczej byciu, choć ku czemu konkretnie - jeszcze nie wiadomo.

Oryginalny tytuł omawianej przez Noikę rzeźby Brâncuşiego brzmi Cumințenia pământului. Słowo cumințenie znaczy słownikowo grzeczność, rozsądek, rozum. Zdecydowałem się przełożyć je jako rozważność, choć nie jestem pewien trafności tego wyboru. Rozsądek wydał mi się zbyt mocno powiązany ze sferą rozumu praktycznego, ludzkiej praksis, czynu, a rozum z kolei zbyt bliski sferze teoretycznej inteligencji; od obu tych sfer, podobnie jak i od piękna, Noica się dystansuje, szuka w rzeźbie czegoś innego. Myśl z kolei - choć Noica wywodzi rumuński przymiotnik cuminte od łacińskiego mens - brzmiała nieco zbyt statycznie. Uznałem, że właśnie w słowach takich jak rozwaga, rozważny, rozważać można doszukać się sensów odnoszących do jakiegoś źródłowego poruszenia, „roz-chodzenia się” myśli $k u$ czemuś, co $w$ niej mocno tkwi, niejako uziemione (ma „wagę”, „ciężar”, także dosłowienie), czyli sensów nieco innych niż te, które odsyłają z jednej strony do czystego aktu myślenia, intencjonalności, spekulatywności, a z drugiej strony do rozumu instrumentalnego.

„Być dziełem znaczy wystawiać jakiś świat” - napisał Heidegger ${ }^{20}$. Dla Noiki tym dziełem są rzeźby Brâncuşiego, a światem stawanie się ku bytowi, które - znów autor Źródta dzieła sztuki - toczą między sobą „praspór”, w którym przejawia się prawda Bycia. Wydaje się więc, że przyimkiem întru, wyrażającym jednoczesne poróżnienie i pojednanie dwóch wielkich ontologicznych kategorii, Noica nazwał to, co w twórczości Brâncuşiego najistotniejsze, zaś jego dzieło potraktował jako najpełniejszy wyraz zarówno swej własnej myśli, jak i najważniejszego, bo ontologicznego doświadczenia, które oferuje sztuka: „Sztuka, w szczególności, to eksplozja stawania się ku bytowi w bezpośredniości świata”; „Przez sztukę wszystko otwiera się ku bytowi” 21 .

Przy wjeździe do Târgu Jiu Niekończqca się kolumna widoczna jest wyraźnie, wznosi się na płaskim, rozległym terenie przed zabudowaniami miasta. Zaparkowaliśmy i podeszliśmy do rzeźby, by zobaczyć ją z bliska i sfotografować siebie „przy” i „na tle”, gdyż zdjęcia samej rzeźby można znaleźć wszędzie, w wielkich ilościach i we wszystkich możliwych ujęciach. Nie udało mi się odnaleźć tego drugiego stołu, o którym pisał Noika. Tym jednak, co chyba najbardziej zapadło nam w pamięć z całej sytuacji, była

${ }^{20}$ Zob. M. Heidegger, dz. cyt., s. 29.

${ }^{21}$ Zob. C. Noica, Despărțirea de Goethe..., s. 276. 
nie sama Kolumna, lecz stojący koło niej policjant. Początkowo, oswojeni już z miejscowymi osobliwościami i ekstrawagancjami, myśleliśmy, że pilnuje tego monumentu przed jakimiś aktami wandalizmu, na przykład dotykaniem, zbliżaniem się na nieprzepisową odległość lub deptaniem trawy koło niego, rychło jednak okazało się, że powód jego obecności był głębszy. Otóż ów policjant spisywał odwiedzających nie w celach bezpieczeństwa, lecz ewidencjonowania - zapisywał kto, skąd, czy z Rumunii, czy zagranicy, ile w sumie osób odwiedziło Kolumnę danego dnia. Najwyraźniej włodarze Târgu Jiu wzięli sobie za punkt honoru sporządzenie katalogu gości, których do ich miasta, niezasobnego zresztą w atrakcje, przyciagnęła słynna rzeźba. Może robili potem jakieś statystyki i wykresy. Sympatyczny stróż prawa, trochę zdziwiony nie tyle informacja, że jesteśmy z Polski, lecz tym, że tę informację otrzymał od obcokrajowców w mocno łamanym co prawda, ale jednak własnym języku, długo i skwapliwie tłumaczył, jak dojechać do centrum miasta i znaleźć pozostałe rzeźby. Z tej całej przemowy zrozumiałem tylko jedno: „peste pod”, przez most. Jakiś most tam był, przejechaliśmy przez niego, znaleźliśmy się w mieście, Târgu Jiu nie umywało się do Râmnicu Vâlcea, było bez wyrazu, zatłoczone, duszne, z chaotyczna, mało interesująca zabudowa. Był upał, chwili wytchnienia szukaliśmy w małej kawiarni i jakimś lumpeksie. Brama pocałunku, ulokowana przy wejściu do miejskiego parku, zawładnęły całkowicie młode pary radośnie pozujące do obowiązkowych zdjęć. Położony nieco dalej Stót milczenia budził chyba najmniej zainteresowania, w każdym razie przez dłuższą chwilę, która przy nim spędziliśmy, byliśmy jedynymi zwiedzającymi - o ile to odpowiednie słowo. Być może wydawał się mało atrakcyjny, dlatego że ze wszystkich trzech rzeźb jest najprostszy, jakby najmniej „,artystyczny”, najłatwiej byłoby przejść koło niego nawet go nie zauważając, gdyby nie wiedza, że jest to dzieło słynnego artysty. Pewnie jednak tak właśnie powinno być, jeśli stół i otaczające go krzesła mają pozostać strażnikami nie tylko obecności, ale też nieobecności, zamkniętymi w swym niewzruszonym kamiennym milczeniu, otwierającym jednak na jakąś osobliwą obecność, choć nie jest to obecność żadnej konkretnej rzeczy, lecz raczej jakieś uobecnianie, czy też - skoro Leśmian mówi o nicestwieniu - „obecnienie”.

W moich spotkaniach z Brâncuşim i przy okazji z Noika, niepozbawionych momentów zarówno poważnych, jak i trywialnych, odbyłem drogę niejako przeciwną do drogi przebytej przez samego rzeźbiarza, który z rodzinnej Oltenii wywędrował do Paryża, wykonując ruch od peryferii ku centrum, od tego, co lokalne, do tego, co uniwersalne. Jeśli jednak wierzyć Noice, droga ta nie jest jednokierunkowa, nie prowadzi, w tym przypadku, od tak zwanej kultury małej do tak zwanej kultury wielkiej, a w każdym razie nie narzuca jednoznacznego wyboru między nimi, pociagającego za 
sobą odrzucenie któregoś z elementów. Przypomina bardziej spiralę, która otwiera je na siebie nawzajem, nieustannie odsyła jeden ku drugiemu i jeden w drugim zakorzenia, w kolejnych zataczanych przez siebie obrotach i nawrotach zmierzając ku niekończącym się ontologicznym przygodom.

\section{BIBLIOGRAFIA}

Heidegger M., Źródto dzieła sztuki, [w:] M. Heidegger, Drogi lasu, przeł. J. Gerasimiuk i inni, Warszawa 1997.

Noica C., Creație şi frumos în gândirea filozofică românească, Bucureşti 1976.

Noica C., Cuvânt împreuna despre rostirea filozofică românească, Bucureşti 2000.

Noica C., Despărțirea de Goethe, Bucureşti 2000.

Noica C., Introducere la miracolul eminescian, Bucureşti 2010.

Noica C., Pagini despre sufletul românesc, wyd. II, Bucureşti 2000.

Noica C., Rostirea filozofică românească, Bucureşti 1970.

Noica C., Sentimentul românesc al ființei, Bucureşti 1978.

Pöggeler O., Droga myślowa Martina Heideggera, przeł. B. Baran, Warszawa 2002.

Wodziński C., Kairos. Konferencja w Todtnaubergu. Celan-Heidegger, Gdańsk 2010. 